\title{
Bifocal Distraction in Patient with Rheumatoid Arthritis and Severe Condylar Degeneration. Report of Case
}

\author{
Distracción Bifocal en Paciente con Artritis Reumatoide \\ y Degeneración Condilar Severa. Reporte de un Caso
}

\author{
*Henrique Duque de Miranda Chaves Neto; **Sergio Olate; ***Renato Mazzonetto \& ****Daniel B. Spagnoli
}

CHAVES NETO, H. D. M.; OLATE, S.; MAZZONETTO, R. \& SPAGNOLI, D. B. Bifocal distraction in patient with rheumatoid arthritis and severe condylar degeneration. Report of case. Int. J. Morphol., 29(1):193-198, 2011.

SUMMARY: Facial involvement in patients with rheumatoid arthritis is variable depending on the type, onset, and duration of the disease. The treatment of patients with open bite resulting from degenerative changes on the condyles can be a challenge for the surgeon. Rheumatoid arthritis is a systemic disorder of unknown etiology characterized by chronic inflammation and proliferation of synovial tissue. Studies showed that patients with rheumatoid arthritis can developed progressive osteoarthrosis that result in gross radiographic changes in the condyles. With the development of distraction osteogénesis for treatment of mandible hypoplasia a new chapter has been opened in the surgical management of patients with rheumatoid arthritis associated with skeletal deficiency. The aim of this paper is to evaluate osteogenesis distraction for treatment of anterior open bite in patients with rheumatoid arthritis and severe condylar degeneration.

KEY WORDS: Bifocal distraction; Rheumatoid arthritis; Condylar degeneration.

\section{INTRODUCTION}

Facial involvement in patients with rheumatoid arthritis is related to type, onset, and duration of the disease. The treatment of patients with open bite resulting from degenerative changes on the condyles can be a challenge for the surgeon. Rheumatoid arthritis (RA) is a systemic disorder of unknown etiology characterized by chronic inflammation and proliferation of synovial tissue. The inflammation process results in erosive destruction of the articular cartilage, periarticular e subchondral bone, with associated soft tissue elements (Kamelchuk \& Major, 1995). A key factor in differentiating RA is its systemic nature. Approximately $50 \%$ to $75 \%$ of patients with RA demonstrate temporomandibular joint (TMJ) involving ranging from mild arthralgia to osseous and cartilaginous destruction (Ogus, 1975). Involvement of the TMJ in children and teenagers with juvenile rheumatoid arthritis has been documented to be as high as 50\% (Mayro et al., 1991).

Studies showed (Engström et al. 2007; de Leeuw et al., 1993) that patients with RA can developed progressive osteoarthrosis that result in gross radiographic changes in the condyles. The changes described for the condyle are typical of the deformity in the terminal stage of the osteoarthrosis. They consist of flattening of articular surface, a decrease in the size of condyle and sometimes dorsal bending of the condyle, and sclerosis of articular cortical bone (degenerative joint disease) (Helenius et al., 2006).

According to the literature (Ogus), the development of an anterior open bite may occur in patients with progressive and severe condylar degeneration originally from degenerative joint disease and rheumatoid arthritis.

With the development of distraction osteogenesis for treatment of mandibular hypoplasia a new chapter has been opened in the surgical management of patients with rheumatoid arthritis associated with skeletal deficiency.

\footnotetext{
Assistant Professor, Department of Oral and Maxillofacial Surgery, Dental School, Federal University of Juiz de Fora, Brazil.

** Assistant Professor, Division of Oral and Maxillofacial Surgery, Medicine School, Universidad de La Frontera, Chile.

*** Full Professor, Department of Oral and Maxillofacial Surgery, Piracicaba Dental School, State University of Campinas, Brazil.

***** In private practice, Charlotte, NC., United States of America.
} 
If bone lengthening is required in both horizontal and vertical vectors, a bifocal distraction device is indicated. Molina \& Ortiz-Monasterio (1995) described a bifocal distraction technique with a bi-directional appliance. Guerrero et al. (1999) described the use of intraoral bifocal distraction multiplanar appliances where a bi-directional was performed to correct mandibular deficiencies (i.e., anterior openbite and vertical maxillary deficiency). They did two separate osteotomies, one on the body and other on the ramus.

The use of this technique for treatment of patients with anterior open bite and vertical bone deficiency in patients with TMJ ankylosis was described by Papageorge \& Apostolidis (1999) and later on by Mackool et al. (2006) and Singer et al. (2006).

The concern for temporomandibular joint dysfunction originating from distraction is minimal as compared to changes arising from other orthognatic surgical procedures. Morphologic changes can occur in the TMJ after distraction but these effects are minimal and reversible (McCormick et al., 1995).

The aim of this paper is show the indication of osteogenesis distraction for treatment of anterior openbite in patients with rheumatoid arthritis and severe condylar degeneration.

\section{CASE REPORT}

A 22-year-old female was seen in our clinic with a chief complaint of limited opening of her mouth, pain, and progressive changes in her occlusion for approximately oneyear prior to referred to our practice. A history of grinding, clenching, symptoms of clicking and pain, and creptant noises in her right temporomandibular joint was verified. She did not recall any trauma or distinct event associated with the onset of her symptoms. Her medical history is remarkable for polyarticular juvenile rheumatoid arthritis.

Clinical facial examination showed mandibular deficiency, increased anterior lower facial height and development of steep mandibular plane angle. The maxillary and mandibular dental midlines were normal, with maxillary incisors exposed $4 \mathrm{~mm}$ at rest and $9 \mathrm{~mm}$ at smile (Fig. 1).

Intraoral examination showed a healthy adult dentition with Class II malocclusion, $5 \mathrm{~mm}$ of overjet, $4 \mathrm{~mm}$ of openbite and premature occlusion on the left posterior. According with the patient, the anterior openbite developed during the last year (Fig. 2).

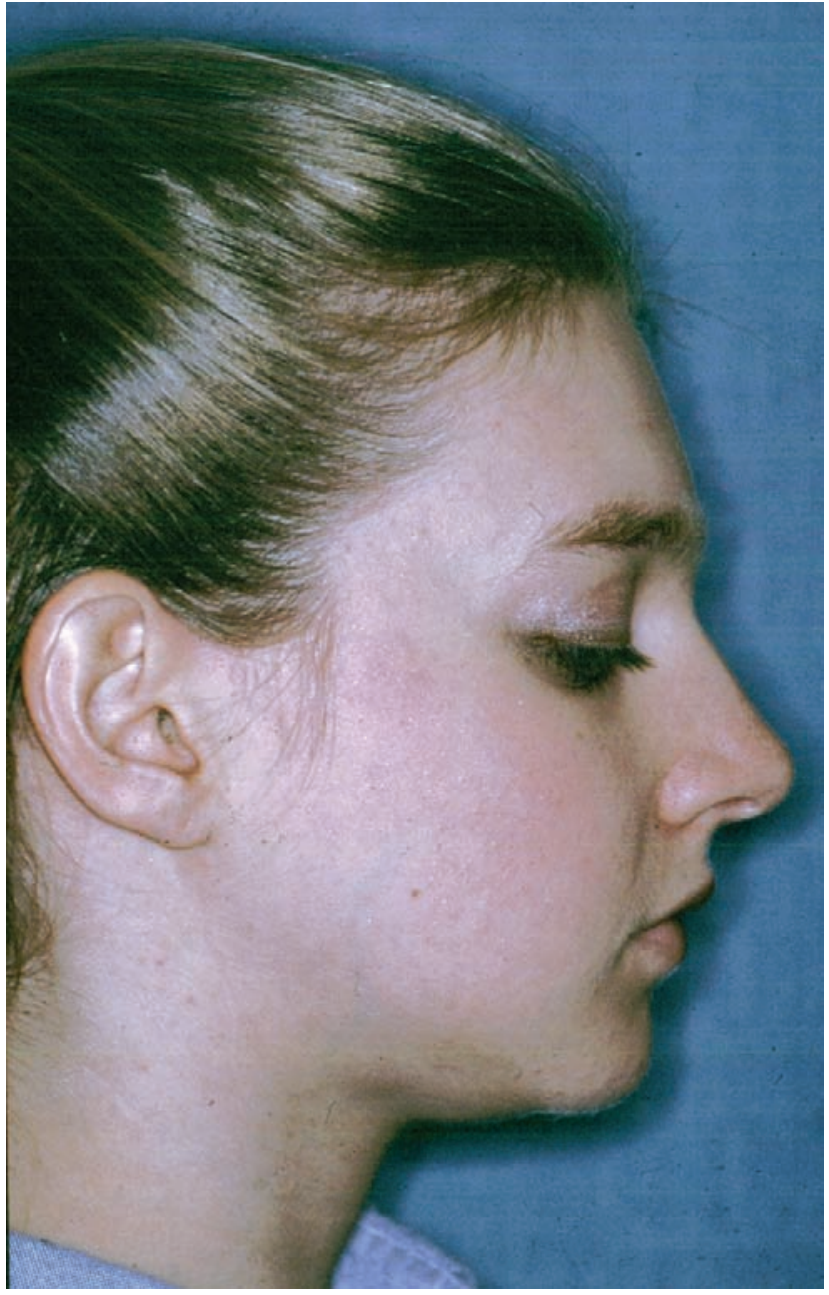

Fig. 1. The extraoral view show altered facial class II profile.

Panoramic radiograph and CT scans were consistent with degeneration of the right and left mandible condyle. MRI showed very small condyles to the point where they were totally flattened, with approximately $5 \mathrm{~mm}$ of vertical loss, fossa remodeling, and the disc tissue adhered to the roof of the fosse.

Initial management of the patient was aimed for stabilization of the resorption process. Splint therapy was prescribed and the patient was instructed in physical therapy methods. At this point, the inflammatory aspects of the rheumatoid disease were being controlled with appropriate medications prescribed in conjunction with her rheumatologist.

Lateral cephalometric and panoramic radiographs were taken after 6 months of nonsurgical therapy and the results did not show any change in the anatomy and morphology of her condyles (Fig. 3). No clinical changes were noted in her openbite or overjet occlusion. 


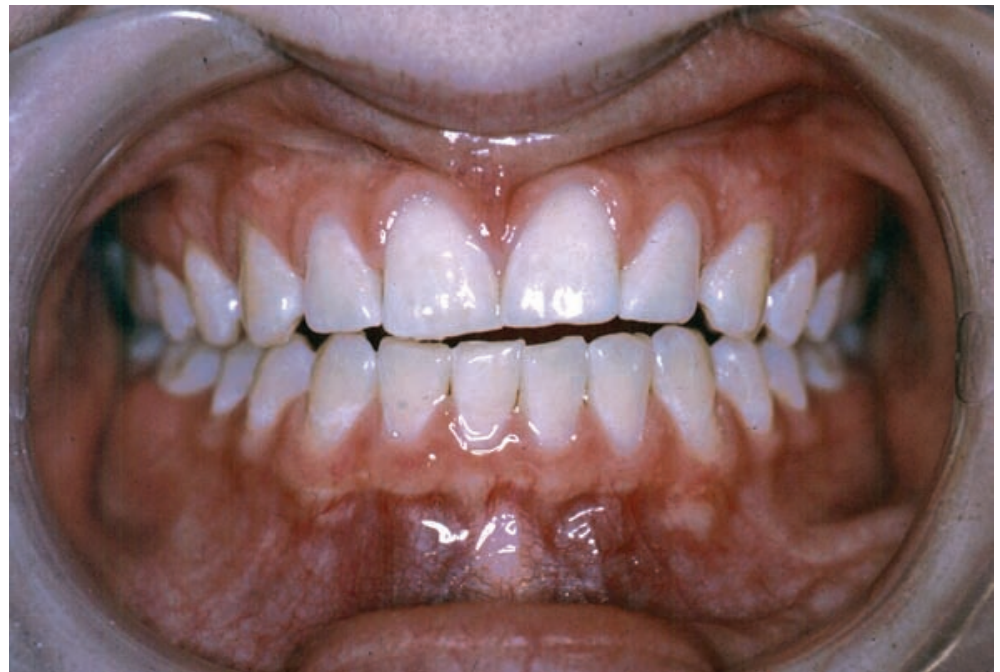

Fig.e 2. Intraoral view showing a Class II malocclusion, $5 \mathrm{~mm}$ of overjet, $4 \mathrm{~mm}$ of openbite and premature occlusion on the left posterior.

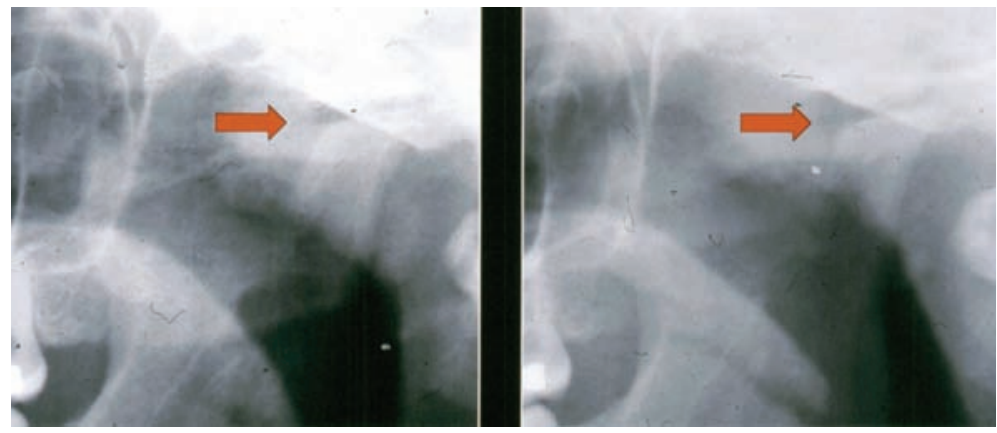

Fig. 3. Panoramic image, showing very small condyle to the point where they were totally flattened, with approximately $5 \mathrm{~mm}$ of vertical loss with a fosse remodeling. For the two evaluations, at different times, observed the same situation was observed.

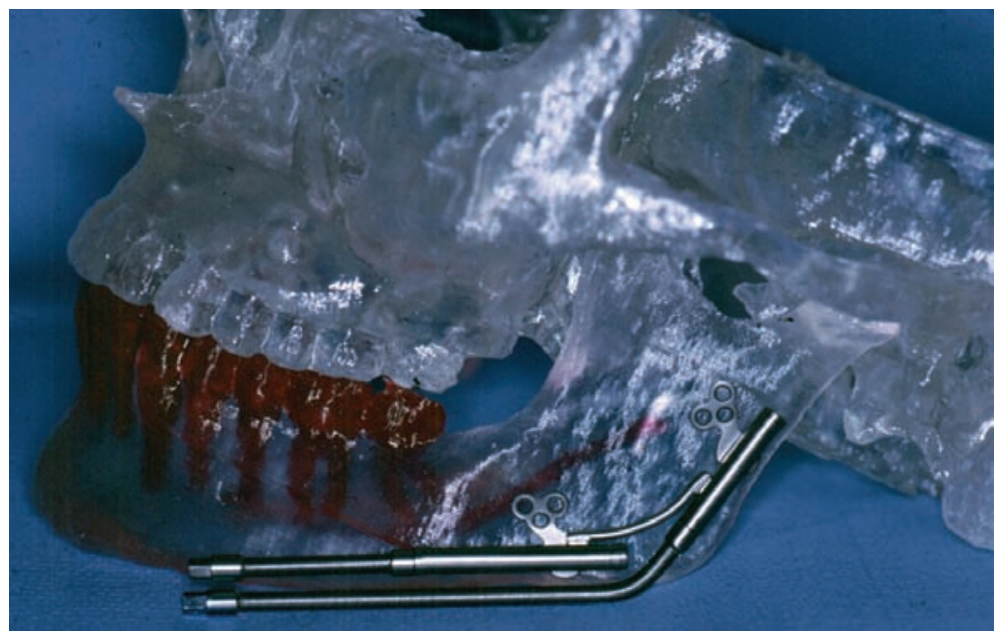

Fig. 4. Intraoral biphasic distractor device designed to achieve vertical and anteroposterior mandibular distraction with one line of osteotomy. Both connectors that are exposed to the oral cavity allow activation of the device in two different vectors.
Computer assisted cephalometric planning study was accomplished to simulate the vectors of distraction and the desired post-treatment positional change of the mandible. A stereolithographic model was obtained for planning distractor placement and the surgical approach. Distraction osteogenesis procedure was then planned using a bi-directional distractor to increase the ramus and body length of the mandible, in order to guide the mandible back into an appropriate relationship with maxilla. A vertical increase of the ramus height combined with mandibular lengthening was accomplished by a new design of intraoral distractor (KLS Martin LP, Jacksonville FL, USA) (Fig. 4)

Operative Procedure. Under general anesthesia, a retromandibular skin incision and dissection was used to exposure the mandibular ramus bilaterally. The distractor devices were placed using $1.5 \mathrm{~mm}$ screws, according to the vectors of distraction and the anatomical position of the inferior alveolar nerve. With the distractor in place, a sagittal saw was used to create a mandibular osteotomy the posterior aspect of the ramus through the sigmoid notch and posteriorly to the angle region of the mandible (Fig. 5). The distractor was verified to be able to move the segments in them proper direction. The two flexible ends of the distractors were then adapted medially in the buccal vestibule of the lip follow by a 3-0 chromic gut suture of the muscle layer and mucosa.

A seven day latency period was allowed for healing before initialing distraction. The distractor activation was commenced at a rate of $1 \mathrm{~mm}$ per day and rhythm of 2 cycle per day $(0.5 \mathrm{~mm}$ per cycle). A close follow up permitted more or less activation of the vertical or horizontal distraction according to the achievement of the desired occlusion. After this, a class II elastic were placed and a consolidation period of 40 days were performed. A second surgery for removal the devices was performed after 45 days (Fig. 6).

A careful follow-up was made. After 10 months postoperative the patient was functioning well with an interincisal opening of $41 \mathrm{~mm}$ and no pain. A normal occlusion was achieved and maintained (Figure 7). The panoramic radiographic at 10 months showed no degenerative changes in the condyles. 


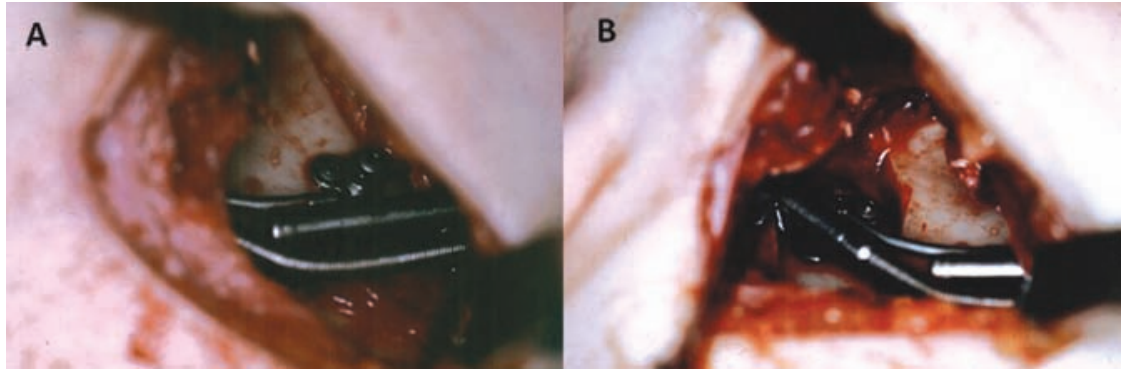

Fig. 5. Surgical situation, showing (A) the distractor in position and (B) the osteotomy executed, evaluating the mobility of the structure.
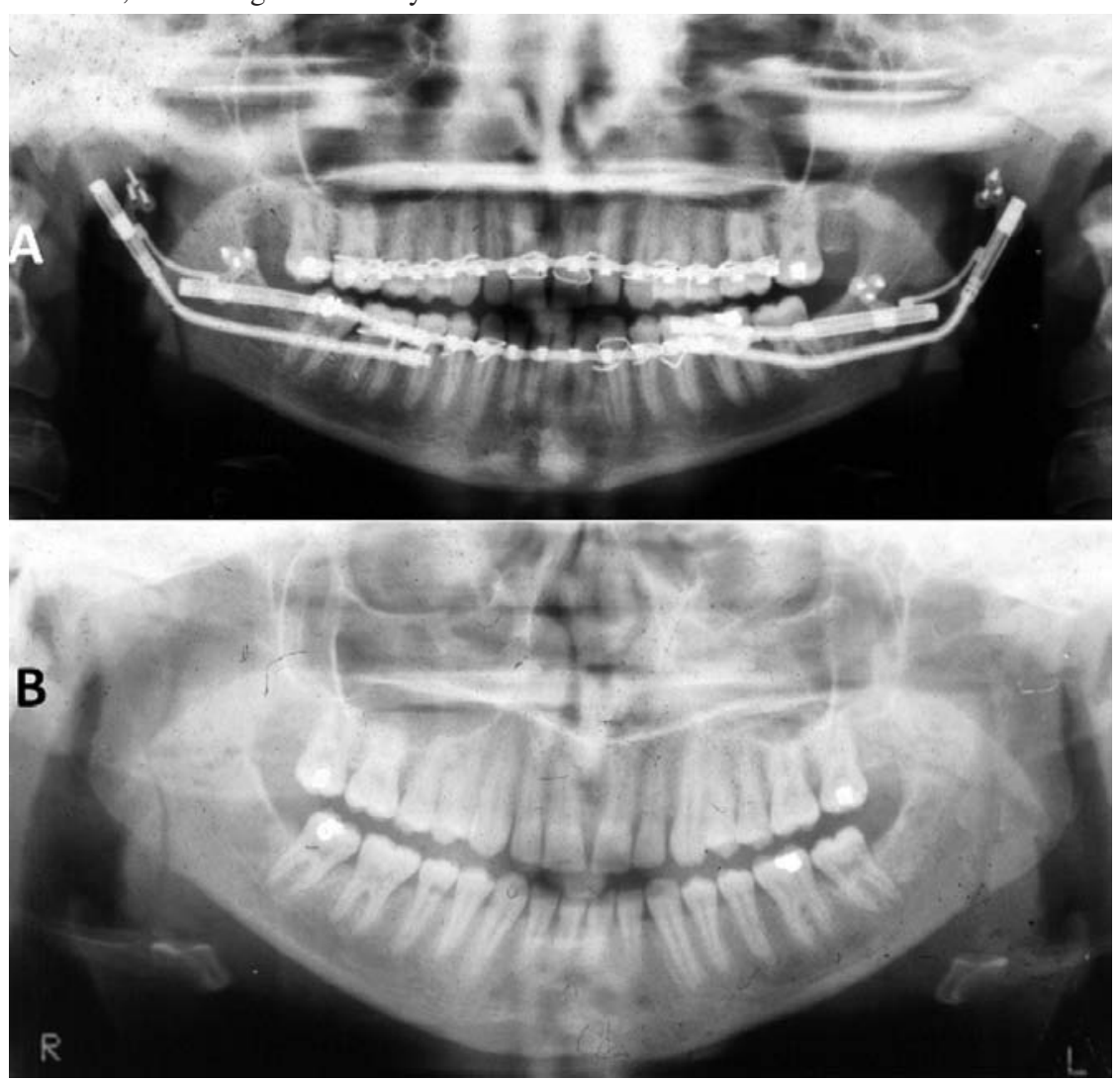

Fig. 6. Panoramic image showing (A) the distractor in position after the surgical procedure (3 weeks) and (B) no degenerative changes in both condyles after 8 months.

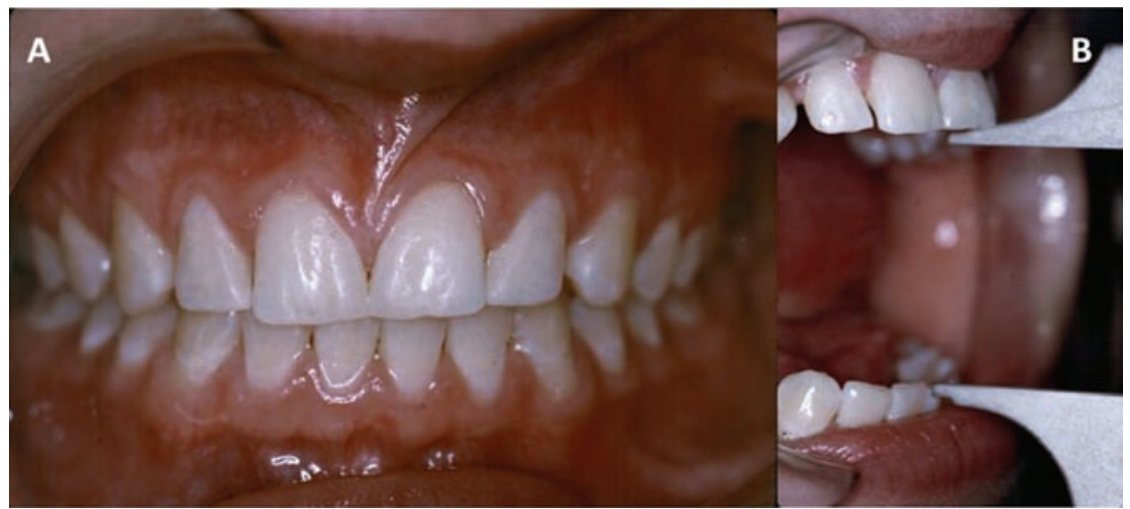

Fig. 7. (A) Final occlusion after 10 months with no open bite and (B) adequately mouth opening with 40mm approximately.

\section{DISCUSSION}

The management of patients with RA and temporomandibular joint degeneration and pain associated with skeletal deformities could be a challenge for the surgeon.

According to the literature (Ogus), the development of an anterior openbite may occur in patients with progressive and severe condylar degeneration originally from degenerative joint disease and RA. This find was observed in our case, where the patient had developed an anterior openbite malocclusion secondary to RA with the effect of condylar degeneration on the right and left side. A perpetuating factor could be the occlusal grinding and clenching, but this may be a manifestation of the premature occlusion. An important factor to be considered previously the surgery was the control of the inflammatory aspects of the rheumatoid disease with drugs and splint therapy in order to decrease the joint load. For the long-term health maintenance, the continuous use of the medications and night splints will be necessary.

After 6 months of nonsurgical therapy for controlling the inflammatory process, a panoramic radiograph was taken. The results did not show any change in the anatomy and morphology of her condyles suggesting that the bearing surface of the condyles were the beginning of sclerosis, which was probably indicative of some maturation and less degeneration, with stabilization of the degenerated process.

Three different approaches were executed for this patient to reestablish her previous occlusion. First, orthognatic surgery, combining LeFort I and bilateral sagittal split ramus osteotomy (BSSO) was considered for 
mandibular advancement. Second a distraction osteogenesis procedure with bi-directional device. A third approach included total joint reconstruction with prosthesis associated with simultaneous mandibular advancement.

Nishimura et al. (1997) showed that inward rotation of the condyle frequently occurs after BSSO regardless of the type of fixation used, and the changes in condylar position are within the range of adaptability of the patient. The intercondylar width decreases with a BSSO for mandibular setbacks and increases with mandibular advancement (McCormick et al.). In patients with RA these adaptability is altered and progression of the degenerative process may occur. For this reason we decided for a distraction osteogenesis in order to correct a Class II malocclusion with anterior openbite. The hypothesis for a total joint replacement was rejected at this moment because the age of the patient but not discards in the long-term prospect.

In patients with mandibular deficiency with anterior openbite the initial planning will be a ramus osteotomy to facilitate a vertical increase of the mandibular ramus height follow by a mandibular advancement to correct the Class II relationship and anterior openbite. The occlusal plane serves as a reference line for the planned vertical and horizontal changes of the mandible (Guerrero et al.). By increasing the ramus height, the occlusal plane is decreased and the ramus and the posterior facial height are increased. The mandibular advancement must be done parallel with the desired occlusal plane. These complex movements can usually be best achieved by multiplanar distraction.

Guerrero et al. described this technique using 2 osteotomies on the mandibular ramus and body. In our case, we performed only one line of osteotomy to achieve a vertical increase of the ramus height combined with mandibular lengthening and a new design of intraoral device was used with successfully and clinical applicability. One osteotomy decreases the surgical time and trauma and can be performed intraorally or extraorally. The risk of damage to neural structures is also decrease with vertical ramus osteotomy comparing with two line osteotomies.

Controlled distraction was performed on a $1.0 \mathrm{~mm}$ per day (twice a day) basis subsequent to the 7-day latency period according to Ilizarov's study (Ilizarov, 1989; 1997). The amount of distraction required was estimate preoperatively based on clinical and cephalometric evaluation. No associated complications were observed.

CHAVES NETO, H. D. M.; OLATE, S.; MAZZONETTO, R. \& SPAGNOLI, D. B. Distracción bifocal en paciente con artritis reumatoide y degeneración condilar severa. Reporte de un caso. Int. J. Morphol., 29(1):193-198, 2011.

RESUMEN: El compromiso facial en pacientes con artritis reumatoide es variable dependiendo del inicio, tipo y duración de la enfermedad. El tratamiento del paciente con mordida abierta resultante de procesos degenerativos condilares son desafiantes para los cirujanos. La artritis reumatoide es una enfermedad sistémica de etiología desconocida caracterizada por inflamación crónica y proliferación del tejido sinovial. Algunos estudios han demostrado que pacientes con artritis reumatoide pueden desarrollar osteoartrosis progresiva que resulta en importantes cambios condilares. Con el desarrollo de la distracción osteogénica para el tratamiento de la hipoplasia mandibular se abrió un nuevo capítulo en el manejo quirúrgico de pacientes con artritis reumatoide asociada a deficiencias esqueletales. El objetivo de este artículo es evaluar la aplicación de distracción osteogénica en un caso de mordida abierta anterior en paciente con artritis reumatoide y degeneración condilar severa.

PALABRA CLAVE: Distracción bifocal; Artritis reumatoide; Degeneración condilar.

\section{REFERENCES}

de Leeuw, R.; Boering, G.; Stegenga, B. \& de Bont, L. G. Temporomandibular joint osteoarthrosis: clinical and radiographic characteristics 30 years after nonsurgical treatment: a preliminary report. Cranio, 11:15-24, 1993.

Engström, A. L.; Wänman, A.; Johansson, A.; Keshishian, P. \& Forsberg, M. Juvenile arthritis and development of symptoms of temporomandibular disorders: a 15- year prospective cohort study. J. Orofac. Pain., 21:1206, 2007.

Guerrero, C. A.; Bell, W. H. \& Meza, L. S. Intraoral distraction osteogenesis: maxillary and mandibular lengthening. Atlas Oral Maxillofac. Surg. Clin. North Am., 7:111-51, 1999.

Helenius, L., M.; Tervahartiala, P.; Helenius, I.; Al-Sukhun, 
CHAVES NETO, H. D. M.; OLATE, S.; MAZZONETTO, R. \& SPAGNOLI, D. B. Bifocal distraction in patient with rheumatoid arthritis and severe condylar degeneration. Report of case. Int. J. Morphol., 29(1):193-198, 2011.

J.; Kivisaari, L.; Suuronen, R.; et al. Clinical, radiographic and MRI findings of the temporomandibular joint in patients with different rheumatic diseases. Int. J. Oral Maxillofac. Surg., 35:983-9, 2006

Ilizarov, G. A. The tension-stress effect on the genesis and growth of tissues: Part I. The influence of stability of fixation and soft tissue preservation. Clin. Orthop., 238:249-81, 1989.

Ilizarov, G. A. The principles of the Ilizarov method. Bull. Hosp. Joint Dis., 56:49-53, 1997.

Kamelchuk, L. S. \& Major, P. W. Degenerative disease of the temporomandibular joint. J. Orofac. Pain, 9:168-80, 1995.

Mackool, R. L.; Shetye, P.; Grayson, B. \& McCarthy, J. G. Distraction osteogenesis in a patient with juvenile arthritis. J. Craniofac. Surg., 17:387-90, 2006.

Mayro, R. F.; DeLozier, J. B. \& Whitaker, L. A. Facial reconstruction consideration in rheumatic diseases. Rheum. Dis. Clin. North Am., 17:943-69, 1991.

McCormick, S. U.; McCarthy, J. G.; Grayson, B. H.; Staffenberg, D. \& McCormick, S. A. Effect of mandibular distraction on the temporomandibular joint: Part 1, a canine study. J. Craniofac. Surg., 6:364-7, 1995.

Molina, F. \& Ortiz-Monasterio, F. Mandibular elongation and remodeling by distraction: a farewell to major osteotomies. Plast. Reconstr. Surg., 96:825-40, 1995.

Ogus, H. Rheumatoid Arthritis of the temporomandibular joint. Br. J. Oral Surg., 12:275-84, 1975.

Papageorge, M., B. \& Apostolidis, C. Simultaneous mandibular distraction and arthroplasty in a patient with temporomandibular joint ankylosis and mandibular hypoplasia. J. Oral. Maxillofac. Surg., 57:328-33, 1999.

Nishimura, A.; Sakurada, S.; Iwase, M. \& Nagumo, M. Positional changes in the mandibular condyle and amount of mouth opening after sagittal splint ramus osteotomy with rigid and nonrigid osteosynthesis. J. Oral Maxillofac. Surg., 55:672-6, 1997.

Singer, S. L.; Southall, P. J.; Rosenberg, I.; Gillett, D. \& Walters, M. Mandibular distraction osteogenesis and maxillary osteotomy in a class II division 1 patient with chronic juvenile arthritis. Angle Orthod., 76:341-8, 2006.
Correspondence to:

Dr. Daniel B. Spagnoli

8738 University City Blvd

Charlotte, NC 28213

USA

Telephone: (704) 547-0837

Fax: (704) 547-1274

Email: solate@ufro.cl

Received: 13-11-2010

Accepted: 29-11-2010 